\title{
The Gift of a Vocation: Learning, Writing, and Teaching Sociology
}

\author{
Sherryl Kleinman \\ University of North Carolina at Chapel Hill, USA
}

DOI: http://dx.doi.org/10.18778/1733-8077.16.2.04

Keywords:

Mentoring; Writing;

Teaching; Graduate

School

\begin{abstract}
To write a sociological festschrift for a scholar necessarily means looking at a chain of influence instead of one person. In this essay, I honor William Shaffir, Emeritus Professor of Sociology at McMaster University, who taught me as I worked towards the MA. I examine what I learned from him by starting with my undergraduate experiences at McGill University, where Billy (I never heard anyone call him William) received his $\mathrm{PhD}$. We shared influences there, including those who had studied with Howard S. Becker at Northwestern University. I then turn to my time at McMaster, and how Billy strengthened my knowledge of symbolic interactionism and qualitative methods, as well as taught me important lessons about writing. He also reduced graduate students' anxieties, including mine, through two words: "No problem." My experiences with Billy provided a model of mentoring that challenged the usual hierarchy between graduate students and professors. Those lessons were reinforced as I pursued a PhD at the University of Minnesota and spent two quarters at Northwestern University as a visiting student. These connecting influences helped me write and teach sociology in a largely quantitative department at the University of North Carolina-Chapel Hill, where I lacked the kind of support I had received as an undergraduate and graduate student. I taught there over 37 years, practicing the kind of sociology and mentoring that Billy generously modeled so many years ago.
\end{abstract}

Sherryl Kleinman is an Emerita Professor of Sociology at the University of North Carolina, Chapel Hill. In addition to scholarly books and articles, she writes poetry, creative nonfiction, and essays. Kleinman continues to write sociologically, especially feminist work, and fights against outsiders' encroachment on faculty governance and academic freedom. She is a long-time member of the American Association of University Professors and active in the local chapter.

email address: kleinman@email.unc.edu 


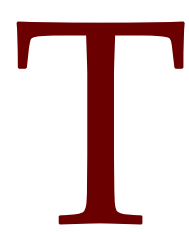

he era of smartphones has not relieved students-or professors-of the burden of convincing others that we are smart. Rather, technology has added one more thing we need to navigate, as I learned when I resisted getting a cell phone, even of the flip variety. I suppose it helped that I was at least 50; Luddite is a derogatory term to many, but has some cachet among old professors. And when undergrads discovered that crossing busy intersections could not stop them from keeping at least one eyeball on text messages and thumbing an immediate response, they developed awe (as in "awesome!") for my ability to live without the temptations of the ready-towear machine. Wait long enough, and you might become cool again.

But, graduate students in sociology, even those working with young professors, must still prove they are smart in the old ways. They take classes, write papers and a thesis, pass comprehensive exams, present papers at conferences, write and defend a dissertation. They contend with mentors and other committee members who expect them to submit papers to journals. The presentations and pubs are not only for those who want a job at an "R1" university, a term I learned about 10 years ago, though I had been teaching at one for 27 years. Having a single-authored publication, perhaps from one's MA thesis, and a few presentations at conferences, are expected for just about any academic position. Even students who whisper that they want a "teaching job" learn that having a $\mathrm{PhD}$ is not enough.

At every turn in graduate school, students know they must prove to professors, the gatekeepers of success, that they are hardworking (including evenings, weekends, holidays, and summers), intelligent, knowledgeable, insightful, and original
(“What's your contribution?," “You haven't answered the 'so what?' question"). Professors evaluate them, even in conversations over coffee; students must continuously show that they are worthy of the honorific title, "professional" (Becker 1970). As Jack Haas and William Shaffir $(1977 ; 1991)$ found in their study of medical students at McMaster University, students learn to adopt a cloak of competence, maintaining gatekeepers' impressions of them as deserving of the title.

And yet, I look back on the years I spent in graduate school and as an undergraduate as the most exciting years of my life in sociology. Like all students, I knew I had to convince professors of my smarts and had anxiety about the quality of my work. But, that did not form the core of my experience as an undergraduate at McGill University, an MA student at McMaster University, a PhD student at the University of Minnesota, or as a visiting graduate student at Northwestern University. I tearfully left graduate school after 5 years, leaving behind graduate student friends and supportive faculty for one of those R1 jobs.

What makes my positive experiences even more surprising is that I grew up with a perfectionistic mother who said when I got $98 \%$ on a test in school, "Did anyone get a hundred?" When I managed to get 100, she said, "Well, that's geography; let's see how you do in history." My upbringing left me with enough doubt and anxiety about the quality of my work, and my self-worth, to last a lifetime.

And in case this sounds like mother-bashing, it is not (see: Kleinman 2002; 2006). My mother emigrated at age 6 with her mother, from Poland to Quebec City, to meet her father for the first time; he had left his pregnant wife to make enough of a living, as 
a tailor, to bring her and his daughter to Canada. My mother, who loved school, quit at the end of grade 9 to help pay for the 4 children who came later. She liked to say she went to university with me because she read some of the books for my classes and many of my papers. She wanted me to become a real doctor, not a PhD, so I would have the money to live a life better than the lower-middle-class one I came from, or the poor one she experienced until she married my father. Much to my mother's chagrin, my father never used his Bachelor of Commerce (1935) from McGill University (he would have been an accountant), but instead took over his father's small printing press-permanent ink under the fingernails included-after his father died suddenly. Perhaps my father's underachieving and his corresponding unease about the high-status volunteer positions my mother held in Jewish organizations amplified my mother's investment in the accomplishments of her children. My brother, 12 years older, became an orthodontist; my sister, 5 years older than me, had test anxiety and did not get into college. Not surprisingly, she thought of herself as a failure and resented it at the same time.

So, how did I manage to escape the worst of the uncertainty and anxieties of being a graduate student? How did I come to thrive?

\section{McGill and McMaster}

I was born and grew up in Montreal, and was expected to attend McGill University and live with my parents while doing so. I did not know anyone who "went away to college" until I met a student from the US who attended McGill, her apartment (I asked) paid for by her father. I told my parents about this American practice, and they said I had a perfectly good home to live in, even if it meant a one-hour bus and subway commute each way. My mother, who always had the best lines, added, "Only a brazen hussy would want to live downtown!" Definitely grist for later feminist memoirs.

In my second year as an undergrad at McGill, I fell in love-with sociology. I did not fall for all of it, nor did I gravitate to a particular topical area. Rather, I connected with a perspective and the method that went with it: symbolic interaction à la Blumer (1969) and Mead (1934), and qualitative methods. I had no career plan attached to sociology at that point, but I somehow believed this love would save me from going to law school, the default for those who did not find a meaningful niche. This was the early 1970s, and I wanted an education that, as we said back then, was relevant-to my life, to the ways I did not fit in with my family, with the Jewish urban community, and with society (a reified term SI unraveled for me). By third year, if anyone asked about my major, I would say breathlessly, "sociology-but-really-symbolic-interactionist-qualitative-research." Sounds obnoxious, but being in love will do that.

At the time, McGill's undergraduate program was 5 years, with 5 courses per semester, so I had longer than usual to take classes, and to push myself to attend the office hours of professors I admired, especially Prue Rains and Joe Lella. I also took statistics with a qualitative sociologist, Malcolm Spector, who was a terrific teacher, but something about him scared me, despite the jeans and beard. Undergrads were not lining up at professors' doors, so I stayed for the two hours, or until they kicked me out. I talked with Prue and Joe (and occasionally with other profs) about papers I was writing, what intrigued me from the readings we had not gone over in class, and asked them to say more about their marginal 
comments on past papers. My grades were good, so they knew I was not there to argue over marks. I still remember what Prue wrote on one of my papers: "This is an elegant analysis, but is it true?" I suppose that should have stung, but I had talked with her so many times that I could hear her voice, going over the analysis, rather than cutting me down. I was excited, anticipating the conversation we would have about her comment. Prue's main point? Do not make the analysis overly complicated, just complicated enough.

Some of the intro classes were large, but those had smaller sections led by teaching assistants. I took advantage of their office hours as well. I also talked Prue and Joe into giving me independent studies, in which I did in-depth interview projects, transcribed the data, and wrote 30-page papers. Yes, like a graduate student, though I did not realize it at the time. I co-authored one of those papers with another undergrad, and learned about combining friendship and work. I caught the bug, and went on to co-author articles, chapters in edited volumes, and a book. I am retired, and still co-authoring.

What I learned, and then took for granted, is that interactions between students (even undergrads) and professors could be helpful, insightful, and intellectual, as well as informal, non-intimidating, and, dare I say it, fun. For those profs and TAs, I imagine what mattered was whether the student was passionate, hard-working, and curious. Our conversations were anchored in sociological work; I learned how to dig into a project, commit to a process that was alternately arduous and adrenalizing, build an analysis, and communicate it in an accessible way. Yes, I read a lot and used concepts from sociology, but the point was to produce a solid sociological analysis: maybe one day I would write one that was true and elegant.
I could be a student, not in the sense of making the grade (though getting A's helped and I am my mother's daughter and a daughter of schooling), but in the sense of learning, including making mistakes along the way. Even mistake is not quite the right word, as if one had the wrong answer on a math test. Rather, what they pointed out to me deepened my understanding or offered a new way of looking at a phenomenon. I internalized those lessons and turned them into good habits.

In case I sound like a self-confident nerd-having the chutzpah to monopolize professors' office hours, asking for independent studies, including one with another student-I also worried that I would not do the work well enough to become One of Them. At some point I learned, mostly from teaching assistants, that if I wanted to continue doing this kind of work and paying for an apartment of my own, I would have to go to graduate school for several years and then apply for professor jobs. The number of years it might take in graduate school did not bother me; getting paid to be a student-for-life through TAing, teaching, and then working as a professor felt too good to be true. I assumed I was taking a vow of poverty, making my plan all the more virtuous, and I was thrilled at the possibility of having enough money to do what I loved. As I discovered in an undergraduate theory class, this is what Weber meant by having a vocation (Weber 1958; Ferrales and Fine 2005).

Looking back, Prue, Joe, and the TAs mentored me, and in ways that reduced the hierarchical differences between us; I think Prue and Joe were tenured associate professors at the time They treated me as a serious sociologist-in-the-making. This kind of relationship between teacher and student is an example of what Jean Baker Miller (1987) calls tem- 
porary inequality; the teacher's goal is to make the student (eventually) into a peer. Permanent inequality means what it sounds like; people in positions of authority stay invested in maintaining dominance over subordinates.

The profs and TAs were committed to doing good sociological work and I never thought of them as climbers. They did not give me mini-lectures in their offices unless I asked for one; office hours became an invitation to conversation. They asked me questions that mattered rather than questions that tested how smart I was. Maybe they were doing both, but I did not pick up on it. After years of living with my parents, schooling, piano exams, and pre-company ballet, I was likely to pick up on testing. The profs and TAs gave me the gift of treating me as a student-scholar at age 19, and I never felt called upon to satisfy their egos as scholars. Their informal, almost casual style put me at ease. They put sociological work at the center, not me.

Then the bad news came. I applied to Northwestern University's sociology department for graduate school (Prue had gone there for her PhD) to work with Howard S. Becker. Prue encouraged me to apply. I felt good about everything in my file-except my GRE scores. I did not know there was an industry, even back then, to help students improve their scores, including books to prepare for the test. [Or, am I still justifying those scores? Schooling's effects run deep.] Prue was surprised I did not get in, even after I confessed my mediocre scores.

I had also applied to McMaster (Allan Turowetz, a TA I came to know at McGill, planned to go there for his $\mathrm{PhD}$ ), University of Minnesota (still something of an SI haven), and University of Toronto (a "good school" in Canada). I got into these depart- ments, though I was disappointed that I would not get to study with Becker. The good news is that I got a one-year Canada Council MA scholarship that enabled me to go to a Canadian university. My fantasy, as an urbanite, was to get a job in Toronto after finishing a PhD. Just far enough away from my family in Montreal to avoid Friday night dinners, and close enough to visit several times a year. A TA told me that departments usually did not hire "their own," so I took the scholarship to McMaster rather than Toronto. I also kept the door open at Minnesota; my acceptance was deferred for a year.

And what a year that was. William Shaffir (Billy to everyone) was my appointed advisor. I also got to know another professor, Jack Haas, and learned about Billy and Jack's fieldwork at the campus medical school. Billy's PhD was from McGill, where he had worked with Malcolm Spector. Prue also influenced Billy, and Malcolm and Prue had both studied with Becker. In addition, Prue had chaired Allan Turowetz's MA committee at McGill, and Allan knew Billy. With all these connections, it is unsurprising that McMaster built on my work as a symbolic-interactionist-qualitative-researcher. Better yet, I did not need to announce the string of words to Billy and Jack; they already knew, and did not ask "What's your area?" Billy had studied the Chasidic community in Montreal, but was now studying a medical school; Jack had studied high-steel ironworkers and was now studying the medical school with Billy. Becker had studied jazz musicians and school teachers, among other groups. Moving across "areas" made sense despite the way most sociologists cut up the field.

I do not remember if McMaster asked for GRE scores, but Billy and Jack focused on my work. Billy also ensured that schooling would not interfere with my education. Each time I complained to him 
about a bureaucratic rule that stood in my way, he said: "No problem." At first I thought he was joking. But, he always came through. Billy never told me what he did, but the problems disappeared. Billy had my back.

I asked him to read a paper I had written for an independent study with Prue about sexual identity and experiences among college women (I had interviewed undergraduate heterosexually-active students). He gave me comments and asked if he and Jack could include it in a volume they were editing. The process became instructive. I had used Goffman's (1961) concept of "moral career" in the paper, and Billy said he was not sure I was using it in the way Goffman intended. Uh-oh, big mistake? Billy said something like, "You could see if what you found really does fit with moral career, or argue that you're using the concept in a different way because your case adds something to it, or just drop 'moral career' and use something else." He said this in an unremarkable tone, as if what I faced was a typical matter that sociologists encounter. [“No problem.”] The lesson stuck.

Here is another lesson. I dropped into Billy's office and found him looking at a manuscript on his desk. He turned it around to face me. "Sherryl, look at this." He ran his finger slowly over the lines, and I could see cross-outs and substituted words. Two sentences in a row had a line running through them. What was he showing me? Beaming, he said, "Can you believe it? Howard Becker edited our paper!" I was confused; a famous sociologist had "corrected" the paper Billy and Jack were working on and Billy felt good about it. At least Becker had not used a red pen. Billy made it clear that Becker's editing was a gift.

I also had a pang of envy, reminded that Northwestern had rejected my application and I would never see edits on my work from Becker. But, the importance of having sociologists edit each other's work stayed with me. As Daniel Chambliss (1989) wrote later in "The Mundanity of Excellence," hard work is not enough; one needs to learn, and then practice, all the right things, including the little ones. Comments and cross-outs are valuable.

Billy also knew when to let a student go. After a few months, I talked with him about whether to transfer to the University of Minnesota for the PhD. I had visited the sociology department there, met faculty and graduate students, and heard it was possible to study at any of the Big Ten schools (I did not know it was a sports designation) for up to a year. Northwestern and Minnesota were on the list, and a current student from Minnesota was doing just that. Maybe I would get to take a class with Becker. Billy told me to go, that I would learn new things from other people. He wrote a recommendation letter for the 4-year $\mathrm{PhD}$ Canada Council fellowship that one could take anywhere. I got the fellowship, but I was nervous about leaving; McMaster's sociology department felt like home. And who knew if near-collegial relationships were possible between graduate students and faculty in the States. Billy nudged me out.

\section{Minnesota and Northwestern}

The informal and work- rather than performance-centered relationships I had with faculty at McGill and McMaster made it possible for me to develop a quasi-professional identity well before I received my PhD. I did not experience culture shock in graduate school in Canada or the US. I had not become test-wise (the skills of a student), but I had learned how to think sociologically. Prue and Joe and Billy and Jack made me feel like a sociologist rather than a student. 
I have not said much about peers, though I mentioned co-authoring with an undergraduate at McGill. I wrote a paper at McMaster about first-year graduate students (yes, when I was one), publishing it several years later (Kleinman 1983). I chose that group not only for convenience. What surprised me at McMaster was that students, including me, pretty much developed a leisure culture; the content was anything-but-sociology. With the exception of one graduate student I became close friends with (we later co-authored an article), sociology became something one (presumably) did on one's own rather than in conversation with peers. In interviews, students said they even saw spending too much time with faculty as suspect; the goal was to prove oneself as a lone scholar. I wrote about the model of individualism in graduate school (do your own work, talking or working with others is close to cheating) and individuation (be original, hunching over your desk until you discover something no one has thought about before). Sociological work was meant to be asocial.

With the exception of a couple of students, I found the same peer culture at Minnesota. I talked about work with faculty, including a new assistant professor, Gary Alan Fine, and occasionally with two old-timers, Gregory Stone and Harold Finestone. Gary and I co-authored articles, based on the weekly meetings he initiated. I wonder if students' gossip, complaints about a department, and shared leisure pursuits tamp down competition (Puddephatt, Kelly, and Adorjan 2006) and allow supportive friendships to develop. After all, students will be getting letters from some of the same professors and will compete in a shrinking job market. In graduate school, talking about one's work or how much one accomplished in a day could lead to negative self-comparisons. Not a good basis for friendship, something every lone scholar needs.
After a year at Minnesota, I wrote Becker (Howie, once you meet him) and asked if I could take his fieldwork course through the program linked to the "Big Ten" schools. He said yes, and I flew to Chicago from Minneapolis in early January for the winter quarter. The first-year cohort adopted me. Most of them took the course because it was required; few expected to do fieldwork for their dissertations, and planned to work with other faculty. I got a dorm room in a Protestant seminary on campus because it was cheap and I expected to stay for only 10 weeks. Howie asked us to choose a setting on the first day, and I chose the seminary because I did not know Evanston or Chicago. My experience was immersive: I lived there, attended classes, ate in the dorm cafeteria, and hung out with the students. I became obsessed with the project, turning in voluminous fieldnotes and lengthy interview transcripts to Howie. During his office hours I shared my anxieties and excitement about all matters fieldwork, including the story I was trying to figure out. The intensity was heightened by the ticking clock.

At first I worried about impressing Howie; never mind his informal name and demeanor, I knew he was famous. I had devoured his work at McGill and McMaster, and... Northwestern had rejected me. But, I was not a student at Northwestern and knew I would be leaving soon, so I did not have much time to worry about what he thought of me. Instead I lived as a fieldworker. After 3 weeks, Howie suggested I stay another quarter to gather enough data for a dissertation. The D-word? I was only in my second year at Minnesota. He gave me independent studies for the spring quarter so I could continue my work and got me a TAship for an undergraduate fieldwork course that another professor would be teaching in the spring. 
At Northwestern I also learned about competition. Howie told me to get in touch with students whose committees he chaired, and that is where I found an unexpected chill. On the phone I found myself talking them into meeting with me, even after stating that Howie told me to initiate contact. Perhaps they resented the fact that Howie was treating me, a visitor from a lesser-status sociology department, as an honorary Northwestern student. These students might have wanted the TAship; the undergraduate class was unusual, a special program in which students received a full quarter's credit (usually, 3 courses) for doing full-time fieldwork. I too found it surprising that Howie had called the professor to refer me for the job. I learned later that the Northwestern students I met had gone to elite liberal arts colleges, and Northwestern was a continuation of that kind of education. My mother considered McGill the Harvard of Canada, but graduate students knew almost nothing about Canada ("Toronto is the capital, right?"), including its universities. I also surmised, through my observations of Howie's students, that his informal style made it harder for anyone to figure out who would get the better letter for jobs. If memory serves, faculty at Northwestern decided which students should apply for which jobs, perhaps to cut down on competition between students in the pool of applicants. But, whichever way one cuts it, students who know each other may find themselves competing on the job market. I imagine they wondered, "Who was this outsider that had Howie's attention?"

I did not expect a letter and that freed me to learn. I watched carefully as Howie took a student's analysis in the fieldwork course and turned it on its head. I want to know how to do that. I kvetched to him in his office about paradoxes in my data and he asked the right questions to keep me moving. I gave him drafts of articles I was writing with Gary Fine, and he gave us comments. At some point I confessed that I had not been admitted to Northwestern. "Well, obviously the committee was wrong," he said.

It helped that Howie's main criticism of graduate school is that it prepares students to become students (e.g., writing comprehensive exams) rather than professionals. Howie wrote comments on my drafts of articles and dissertation chapters well after I returned to Minnesota, and into my years as an assistant professor. That included light editing. And yes, he did write letters for me when I applied for jobs. When I called to tell him I had accepted the offer from the University of North Carolina (UNC), Chapel Hill, he said, "Well, too bad it's not in a city." Exactly.

\section{UNC-Chapel Hill}

The performance model kicked back in when I got the job at UNC, Chapel Hill. I had never heard of the school or the department, but professors at Minnesota had, and those I had never met introduced themselves and congratulated me after word spread about the offer. Chapel Hill is a small town (I learned the concept of "college town" here), and I was one of only two women (the other woman, also an assistant professor, had arrived a year before). Almost all the profs were doing quantitative work, most of them senior in status and age, and they interacted in a formal way that made me uncomfortable. I felt like a kid among the grown-ups. The two male assistant professors spoke with professorial voices. The senior graduate students (around my age, some of them older) became my reference group and, to some extent, my membership group.

I had been in semi-collegial relationships with faculty for years by that point, but now my mind and body returned to childhood and schooling. Any untenured 
faculty member surely feels performance anxiety; after all, the stakes are high. But, for me, moving to the department and town was no less than culture shock. I shrank at faculty meetings, felt anomic in the department and bored in the town, and had to learn to teach. Faculty in the department were polite, but where was the liveliness? The chair had said in our first meeting that my sole concern should be publishing (as if I did not know?) and that "it's OK to be a mediocre teacher." He said nothing about the content of my work, but the publish-or-perish message was clear. Lacking connection with students, I dreaded going to my undergraduate class of 80 bodies. I eventually found ways to teach and new courses that brought me closer to undergraduates-the very students I was supposed to see as standing in the way of research. And I wrote about it (Kleinman 1999; Kleinman, Copp, and Sandstrom 2006; Kleinman and Copp 2009).

My claim that I returned to childhood must sound like an exaggeration, but here is one story. At the start of my third year at UNC I found out that my dissertation on the seminary students, which I had revised into a book, would be published by the University of Chicago Press. I called my mother to tell her the news, and I mentioned Chicago (having informed her about the hierarchy of presses). She said, “The book. That's good. And I know the press is important. But, there'll be more books. You're not the type to rest on your laurels." After I said good-bye to my mother, I went into my department chair's office to make the same announcement: "That's good news about the book and Chicago is a great press. But, as you know, it's what you do next that counts." For a second, I thought my mother and my chair were in cahoots, believing they had found the way to ensure my productivity. But, they did not need to collaborate. It turns out that my mother had prepared me for the pressures of working in a highly-ranked academic department.
As she said often when I was in school, "You need to be ten steps ahead to stay afloat." She did not say that because I was a woman, but because I was a Jew. And being secular would not help.

But, what $I$ learned is that wearing the cloak of competence takes a heavy toll; the kinds of interactions I had with professors as an undergraduate and graduate student shored up my confidence and freed me to experience the work as meaningful. I came to do the same for students I taught and mentored, connecting with them in an informal style and challenging their thinking and practices in a friendly way. Graduate students at UNC suffered the anxiety that goes with the performance model, but my seminars became a place for us to talk about that (we read Jack and Billy's article about the cloak of competence). I created spaces in which students could bond over shared vulnerabilities and analysis rather than connecting only through department gossip.

I encouraged students to create writing groups (I taught a writing seminar similar to the one I took with Howie). The students I mentored created qualitative working groups, and each of them knew I would comment on multiple drafts of papers/articles and chapters of dissertations, including lightto-heavy editing. They also learned to share early drafts among themselves, give constructive criticism, and edit each other's work. I told them there were enough journals out there for everyone to publish, and that collaboration rather than competition would make everyone's work better. It helped that SI and qualitative research held a marginal status in the department. You had to be highly committed to doing this work, knowing that other faculty and graduate students thought you had taken the wrong path. That status built solidarity among students. 
It is hard being a new faculty member. There is no cohort to belong to and you have to figure out the department, the university, and how to make friends. Early on, I pushed myself to find qualitative researchers in other departments, then called department assistants to find out the professors' office hours, and showed up. They would have to talk to me. Yes, the same strategy I used as an undergraduate and graduate student. I also went to new professor events, looking for colleagues and friends. And I stayed connected to friends from graduate school through long-distance calls and visits, and met symbolic interactionists and qualitative researchers at conferences, something my mentors told me to do in graduate school. I also stayed in touch with Prue, Billy, Gary, and Howie, sending them drafts of papers.

I developed a variety of body pains, what I call sociosomas; I got a lot of work done, but did not have

\section{References}

Becker, Howard S. 1970. “The Nature of a Profession.” Pp. 87-103 in Sociological Work: Method and Substance, edited by H. S. Becker. Chicago: Aldine.

Blumer, Herbert. 1969. Symbolic Interactionism: Perspective and Method. Englewood Cliffs, NJ: Prentice-Hall.

Chambliss, Daniel. 1989. “The Mundanity of Excellence: An Ethnographic Report on Stratification and Olympic Swimmers." Sociological Theory 7:70-86.

Ferrales, Gabrielle and Gary A. Fine. 2005. "Sociology as a Vocation: Reputations and Group Cultures in Graduate School." American Sociologist 36:57-75.

Goffman, Erving. 1961. Asylums: Essays on the Social Situation of Mental Patients and other Inmates. New York: Doubleday. the energy to apply for jobs. I hung on, got tenure, and two years later met Michael Schwalbe (at NC State University), another interactionist, and someone who lived out his politics more than I did. We have been partners for more than 30 years, and that relationship made it easier for me to bring feminism into my interactionist work and to become a thorn in the side of high-level administrators. Finding and working with progressive faculty across campus also brought new friendships.

I still do not care much for the town and the department never became a professional home. But, when I feel sorry for myself for having landed in a department of quantoids (Norman Denzin's apt term), I remember that I was lucky enough to get a job that allowed me to do the work I fell in love with so many years ago. Overall, as Billy would say, no problem.

Haas, Jack and William Shaffir. 1977. “The Professionalization of Medical Students: Developing Competence and a Cloak of Competence." Symbolic Interaction 1:71-88.

Haas, Jack and William Shaffir. 1991. Becoming Doctors: The Adoption of a Cloak of Competence. London: JAI Press.

Kleinman, Sherryl. 1983. "Collective Matters as Individual Concerns: Student Culture in Graduate School." Urban Life 12:203-225.

Kleinman, Sherryl. 1999. "Leaving the Stage." Salon. Retrieved April 02, 2019 (https://www.salon.com/1999/07/06/lecturn/).

Kleinman, Sherryl. 2002. "Always Rinse Twice." Feminist Studies 28:573-583.

Kleinman, Sherryl. 2006. "A Fine Hen." Calyx: A Journal of Art and Literature by Women 23:66-70. 
Kleinman, Sherryl and Martha Copp. 2009. "Denying Social Harm: Students' Resistance to Lessons about Inequality." Teaching Sociology 37:283-293.

Kleinman, Sherryl, Martha Copp, and Kent Sandstrom. 2006. "Making Sexism Visible: Birdcages, Martians, and Pregnant Men." Teaching Sociology 34:126-142.

Mead, George H. 1934. Mind, Self, and Society. Chicago: University of Chicago Press.
Miller, Jean Baker. 1987. Toward a New Psychology of Women. Boston: Beacon.

Puddephatt, Antony J., Benjamin W. Kelly, and Michael Adorjan. 2006. "Unveiling the Cloak of Competence: Cultivating Authenticity in Graduate School." American Sociologist 37:84-98.

Weber, Max. 1958. “Science as a Vocation.” Pp. 129-56 in From Max Weber: Essays in Sociology, translated and edited by H. Gerth and C. W. Mills. New York: Oxford University Press.

\section{Citation}

Kleinman, Sherryl. 2020. "The Gift of a Vocation: Learning, Writing, and Teaching Sociology." Qualitative Sociology Review 16(2):40-50. Retrieved Month, Year (http://www.qualitativesociologyreview.org/ENG/archive_eng.php). DOI: http://dx.doi. org/10.18778/1733-8077.16.2.04 